DOI: https://doi.org/10.32838/2523-4803/70-2-14

УДК [330.35:330.341.1](100:477)

\title{
Грищук А.М.
}

кандидат економічних наук, доцент,

доцент кафедри менеджменту,

Львівський національний університет імені Івана Франка

\section{Hryshchuk Anna}

Ivan Franko National University of Lviv

\section{НЕОБХІДНІСТЬ ЗМІНИ ТЕХНОЛОГІЧНОГО УКЛАДУ НА ОСНОВІ ДРАЙВЕРІВ ЕКОНОМІЧНОГО ЗРОСТАННЯ}

\begin{abstract}
У статті досліджено сутність категорії «технологічний уклад», його технологічне ядро, зміну технологічних укладів в ході економічного розвитку. Здійснено критичний аналіз стану економічного розвитку України відповідно до засад вищих технологічних укладів. Проаналізовано основні світові тендениії економічного зростання, вітчизняні законодавчі ініціативи щзодо інноваційних засад розвитку, на основі чого обтрунтовано необхідність створення передумов для перебудови економіки Украӥни на засадах VI технологічного укладу. Визначено сутність поняття «драйвери економічного зростання». Здійснено аналіз окремих драйверів економічного зростання в країні щзодо створення доданої вартості за витратами виробництва суб 'єктів господарювання за окремими видами економічної діяльності. Запропоновано рекомендації щзодо майбутнього розвитку аграрної сфери Украйни як одного з драйверів економічного зростання.

Ключові слова: технологічний уклад, інновації, наукові дослідження й розробки (НДР), високотехнологічні галузі, NBIC-конвергенція, драйвери економічного зростання, аграрна сфера.
\end{abstract}

Постановка проблеми. Сьогодні у світі набирає обертів VI технологічний уклад, гіпотетичним ядром якого є NBIC-конвергенція, заснована на об'єднанні та синергетичному зусиллі досягнень у сферах нано-, біо-, інфо- та когнітивних технологій (виник термін «NBIC-конвергенція» за першими буквами назв цих сфер, авторами якого у 2002 р. стали американські вчені М. Роко та В. Бейнбрідж). Передбачається, що результатом NBIC-конвергенції має стати злиття цих технологій у єдину науково-технологічну сферу знань, що дасть змогу в недалекому майбутньому створювати штучний інтелект, кіборгів, матеріали з наперед визначеними властивостями, програмувати гени тощо.

Саме VI технологічний уклад сьогодні формує основу економік таких передових розвинутих країн світу, як Японія, країни Південно-Східної Азії, США, Німеччина, Велика Британія, Франція.

У зв'язку з цим Україна не може залишатись осторонь трансформаційних процесів, які відбуваються у цивілізованому світі та спрямовані на вирішення різноманітних соціально-економічних та екологічних проблем не шляхом розвитку й заохочення лише традиційних для конкретних територій проєктів і технологій, а через формування нових бізнес-моделей та систем на основі передових технологій та інновацій, що можуть забезпечити якісно нове економічне зростання.

Аналіз останніх досліджень і публікацій. Серед зарубіжних учених великий внесок у дослідження технологічних укладів, базових технологій та інновацій, драйверів економічного зростання зробили такі вчені, як В. Бейнбрідж [1], С. Глазьєв [2], М. Кондратьєв [3], Г. Менш [4], М. Роко [1], К. Фрімен [5], Й. Шумпетер [6]. Серед українських учених цьому напряму дослідження приділяли увагу Ю. Бажал [7], Б. Данилишин [19], М. Згуровський [8], М. Чумаченко, А. Чухно [11].

Однак через високий динамізм ринку новітніх технологій в умовах глобалізації та інформатизації бізнессередовища постійно накопичуються нові проблеми, пов'язані 3 необхідністю активізації розроблення, впровадження та використання новітніх технологій, визначення нових драйверів задля забезпечення економічного зростання в Україні та переходу до вищого технологічного укладу.

Формулювання цілей статті. Метою статті $\epsilon$ обгрунтування необхідності розвитку нашої держави на засадах VI технологічного укладу з визначенням основних драйверів іiі економічного зростання на основі аналізу нових економічних викликів світового розвитку та місця України в ньому.

Виклад основного матеріалу. Термін «технологічний уклад» почав використовуватися у вітчизняній економічній науці як аналог понять «хвилі (кластери) інновацій» (за Й. Шумпетером та М. Кондратьєвим) [3; 6], «техніко-економічна парадигма» (за К. Фріменом) [5], «життевий цикл технічного способу виробництва» (за Г. Меншем) [4] тощо. Вперше він був запропонований у 1986 р. радянськими економістами Д. Львовим і С. Глазьєвим [9]. 
Згідно із С. Глазьєвим, технологічний уклад $є$ цілісним і стійким утворенням, у рамках якого здійснюється замкнутий цикл, що розпочинається 3 добування й отримання первинних ресурсів і закінчується випуском набору кінцевих продуктів, що відповідають типу суспільного споживання. Комплекс базисних сукупностей технологічно зв'язаних виробництв утворює ядро технологічного устрою. Технологічні нововведення, що визначають формування цього ядра, називаються ключовим чинником. Галузі, що інтенсивно використовують ключовий чинник і відіграють провідну роль у поширенні нового технологічного устрою, є несучими галузями [10].

У табл. 1 представлено характеристику та динаміку технологічних укладів із зазначенням періоду домінування технологій, які притаманні тому чи іншому укладу.

Отже, чим ближче до сучасного періоду, тим коротше період впровадження технологій (з 20 років у I технологічному укладі до 17 років у II і III, 13 років у IV i V, 8 років у VI). Це говорить про те, що на сучасному періоді розвитку технологій час відіграє дуже важливу роль. Хто стає піонером на ринку новітніх технологій, той виграє та забезпечує собі успіх у коротко- й навіть середньостроковій перспективі.

Ще донедавна в сучасній вітчизняній економічній літературі аналізувались п'ять технологічних укладів. Зокрема, академік А. Чухно та інші науковці дослідили, що технологічна структура економіки України на першому десятку XXI ст. була представлена III, IV i незначною мірою V технологічними укладами. За даними офіційної статистики на цей період III технологічному укладу відповідало 1/3 промислової продукції, IV - близько стільки ж, а на V, що визначає постіндустріальний тип виробництв, припадало лише 3-5\%. За експертними оцінками того часу на частку $\mathrm{V}$ технологічного укладу припадало 4,7\% промислової продукції, IV $-42,4 \%$, a III $-52,8 \%$ [11, c. $221-222]$.

Як уже було зазначено, приблизно з 2010 р. стартував VI технологічний уклад, який відкриває нові можливості управління властивостями штучних матеріалів та живих організмів. Однак, на жаль, у 1990-х рр. ми не використали основних драйверів V технологічного укладу, а саме не застосували інформаційно-комунікаційні технології у всіх галузях життя, не зорієнтували економіку на сферу інновацій, інтелектуальних і творчих послуг, а найголовніше - не зрозуміли, що основними рушійними силами економічного зростання можуть стати інформація, нові технології та інтелект.

Нещодавно експерти Всесвітнього економічного форуму та Національної розвідувальної ради США представили прогноз розвитку світу до 2035 р. [13].

1) Сповільнення темпів зростання економіки в усіх країнах. Зокрема, економічне зростання планети в найближчі 20 років не перевищить 2-3\% ВВП на рік. Середні темпи росту економік найбільших країн Сврозони прогнозують на рівні $1,5-2 \%$, Китаю - 3,5\%. Максимальне зростання продемонструють Нігерія,

Таблиця 1

Характеристика та динаміка технологічних укладів

\begin{tabular}{|c|c|c|c|c|c|c|}
\hline \multirow[b]{2}{*}{$\begin{array}{l}\text { Епохи } \\
\text { технологій }\end{array}$} & \multirow[b]{2}{*}{$\begin{array}{c}\text { Технологічні } \\
\text { уклади }\end{array}$} & \multicolumn{3}{|c|}{ Періоди домінування технологій } & \multirow[b]{2}{*}{ Країни-лідери } & \multirow[b]{2}{*}{ Технології, що переважають } \\
\hline & & $\begin{array}{c}\text { початок } \\
\text { розвитку }\end{array}$ & $\begin{array}{c}\text { сильне } \\
\text { поширення }\end{array}$ & $\begin{array}{c}\text { кінець } \\
\text { швидкого } \\
\text { росту }\end{array}$ & & \\
\hline \multirow[t]{4}{*}{$\begin{array}{l}\text { Індустріальна } \\
\text { революція }\end{array}$} & I & $1770 \mathrm{p}$. & $1790 \mathrm{p}$. & $1830 \mathrm{p}$. & \begin{tabular}{|l|} 
Британія, \\
Франція, \\
Бельгія \\
\end{tabular} & $\begin{array}{l}\text { Водяний двигун, текстильні машини, } \\
\text { виплавка чавуну й обробка заліза. }\end{array}$ \\
\hline & II & $1830 \mathrm{p}$. & $1847 \mathrm{p}$. & $1880 \mathrm{p}$. & $\begin{array}{l}\text { Британія, } \\
\text { Франція, } \\
\text { Бельгія, США, } \\
\text { Німеччина }\end{array}$ & $\begin{array}{l}\text { Паровий двигун, вугільна } \\
\text { промисловість, машино- та } \\
\text { верстатобудування, чорна } \\
\text { металургія. }\end{array}$ \\
\hline & III & $1880 \mathrm{p}$. & $1897 \mathrm{p}$. & $1930 \mathrm{p}$. & $\begin{array}{l}\text { Британія, } \\
\text { Франція, США, } \\
\text { Німеччина }\end{array}$ & $\begin{array}{l}\text { Електродвигун, важке } \\
\text { машинобудування, виробництво } \\
\text { сталі, стандартизація. }\end{array}$ \\
\hline & IV & $1930 \mathrm{p}$. & $1943 \mathrm{p}$. & $1970 \mathrm{p}$. & $\begin{array}{l}\text { США, Західна } \\
\text { Європа, Японія }\end{array}$ & $\begin{array}{l}\text { Двигун внутрішнього згорання, } \\
\text { синтетичні матеріали, органічна } \\
\text { хімія, кольорова металургія, } \\
\text { автомобілебудування, атомна } \\
\text { енергетика. }\end{array}$ \\
\hline $\begin{array}{l}\text { Інформаційна } \\
\text { революція }\end{array}$ & $\mathrm{V}$ & $1970 \mathrm{p}$. & $1983 \mathrm{p}$. & $2010 \mathrm{p}$. & $\begin{array}{l}\text { США, Японія, } \\
\text { країни } \\
\text { Південно- } \\
\text { Східної Азії }\end{array}$ & $\begin{array}{l}\text { Обчислювальна техніка, } \\
\text { телекомунікації, інформаційні } \\
\text { послуги, роботобудування, мікро- } \\
\text { й оптоволоконні технології, } \\
\text { біотехнології. } \\
\end{array}$ \\
\hline $\begin{array}{l}\text { Знаннєва } \\
\text { революція }\end{array}$ & VI & $2010 \mathrm{p}$. & $2018 \mathrm{p}$. & $2040 \mathrm{p}$. & $\begin{array}{l}\text { США, країни } \\
\text { ЄС, Китай, } \\
\text { Японія країни } \\
\text { Південно- } \\
\text { Східної Азії }\end{array}$ & $\begin{array}{l}\text { Синтез нано-, біо-, інфо- та } \\
\text { когнітивних технології. }\end{array}$ \\
\hline
\end{tabular}

Джерело: розроблено автором на основі джерел [2, с. 24; 11, с. 221-232; 12, с. 104-105] 
В'єтнам та Філіппіни, а саме лише 4,5-5,5\%. Україна, маючи низький стартовий рівень, навіть за теперішніх темпів економічного зростання (4,6\% у 2019 р.) може залишитися далеко позаду азіатських країн.

2) Посилення протекціонізму в торгівлі, зменшення частки сировинних ринків та зростання обсягів високотехнологічного виробництва. У світовій торгівлі стрімко знижуються ціни й попит на корисні копалини та нафту. Падає виручка від експорту аграрної продукції (-11\% у 2015 р.) та від експорту промтоварів $(-5 \%$ у 2015 р.). У структурі ВВП країн ЄС сільське господарство займає не більше $3 \%$, в Україні - $11 \%$, і це $є$ головним джерелом валютних надходжень. Продукція високотехнологічних галузей, широке впровадження 3D-друку займуть більшість промислових секторів $\mathrm{i}$ підірвуть економіку країн - сировинних експортерів. В Україні 2/3 експорту складає сировина, а саме 33\% аграрної та харчової продукції, $21 \%$ чорної металургії та руди, 3,6\% лісництва. Більш того, частка української промисловості з роками лише зменшується, а частка сировини зростає. Високотехнологічний сектор України є меншим, ніж у більшості передових країн, адже виробляє $0,5 \%$ ВВП та надає роботу $0,5 \%$ зайнятих осіб (наприклад, у Тайвані цей показник становить 13,8\%). У цьому секторі функціонує лише 4,0\% промислових підприємств (189 у 2017 р.). Проте він $€$ найбільш інтенсивним у виробництві продукції та здійсненні інноваційної діяльності [14, с. 19].

3) Посилення частки нетоварного, нематеріального експорту. 32012 р. темпи зростання торгівлі товарами знижуються, а торгівля послугами зростає. Якщо у 2000-2011 рр. послуги мали стабільні 20\% світової торгівлі, то у 2015 р. цей показник зріс до 23\%. У нетоварному експорті за останні десятиліття міжнародний туризм перетворився на потужне джерело іноземної валюти й став четвертою за величиною складовою частиною експорту після палива, хімічних речовин i продуктів харчування. За даними ВТО внесок туризму у світовий ВВП становить $10 \%$, а кількість робочих місць, прямо чи опосередковано причетних до цієї сфери, складає $11 \%$. Україна у 2018 р. посіла 78 місце в рейтингу привабливості для туристів серед 140 країн за версією експертів ВЕФ (у 2017 р. - 88 місце). Хоча б у цій галузі наша держава посилює свої позиції.

4) Збільшення інвестицій у НДР та зростання кількості дослідників. Саме багаті країни та корпорації інвестують великі суми в НДР, які роблять їх основними вигодонабувачами прогресу. Тут лідирують лише шість країн. Японія інвестує в НДР 3,6\% ВВП, Ізраїль - 4,1\%, Південна Корея - 4,3\%, Австрія, Німеччина й Швейцарія - $3 \%$.

В Україні ситуація за останні роки не дуже втішна щодо цих показників. Зокрема, кількість дослідників стрімко падає порівняно з іншими європейськими країнами (3 6,8\% у 2011 р. до 3,9\% у 2016 р.), зменшується питома вага витрат на виконання НДР у ВВП (з 0,65\% у 2011 р. до $0,45 \%$ у 2017 р.) (табл. 2).

5) Відхід від звичайної праці, розвиток креативних видів діяльності. Робототехніка, автопілотні механізми на транспорті сприятимуть зникненню звичайних професій у промисловості та сфері послуг. За даними ВЕФ до 2020 р. у розвинених країнах кількість створених робочих місць на 5,1 млн. позицій буде відставати від кількості скорочених.

Прогресивні країни наполегливо стимулюють креативні види діяльності, оскільки вони удвічі стійкіші до автоматизації. Наприклад, Британія планує створити 1 млн. креативних робочих місць за найближчі тринадцять років. Тим часом в Україні $40 \%$ зайнятих у промисловості робітників працюють на виробництві продукції низького технологічного рівня, $15 \%$ - у видобутку корисних копалин та сільському господарстві порівняно з 1-5\% зайнятих у СС на аналогічних видах діяльності. Отже, невдовзі більшість українських працівників стануть непотрібними, а поширення нових технологій зажадає від фахівців спеціальних знань і навичок. Це посилить економічний розрив між висококваліфікованими та низькокваліфікованими працівниками.

У Глобальному індексі конкурентоспроможності талантів за 2019 р. Швейцарія й Сінгапур посідають лідируючі місця, США й Норвегія - трете й четверте місця відповідно. До топ-10 традиційно входять Швеція, Данія, Фінляндія, Нідерланди, Велика Британія та Люксембург. Позиція України у цьому рейтингу у

Кількість дослідників у розрахунку на 1000 осіб зайнятого населення (віком 15-70 років) та питома вага витрат на виконання НДР у ВВП (дані за окремими країнами), \%

\begin{tabular}{|c|c|c|c|c|c|c|c|c|c|c|c|c|c|}
\hline \multirow{2}{*}{ Країни } & \multicolumn{6}{|c|}{ Кількість дослідників } & \multicolumn{7}{|c|}{ Питома вага витрат на виконання НДР у ВВП } \\
\hline & $2011 \mathrm{p.}$. & 2012 p. & 2013 p. & 2014 p. & 2015 p. & $2016 \mathrm{p}$. & 2011 p. & 2012 p. & 2013 p. & 2014 p. & 2015 p. & 2016 p. & 2017 p. \\
\hline EC-28 & 11,9 & - & 12,9 & - & 13,3 & - & 1,97 & 2,01 & 2,02 & 2,03 & 2,04 & 2,04 & 2,06 \\
\hline Болгарія & 5,0 & 5,2 & 5,6 & 8,1 & 6,5 & 7,1 & 0,53 & 0,60 & 0,63 & 0,79 & 0,96 & 0,78 & 0,75 \\
\hline Естонія & 13,1 & 12,9 & 12,6 & 12,9 & 11,7 & 11,2 & 2,31 & 2,12 & 1,72 & 1,43 & 1,47 & 1,25 & 1,29 \\
\hline Іспанія & 12,0 & 12,3 & 12,3 & 12,2 & 12,1 & 12,0 & 1,33 & 1,29 & 1,27 & 1,24 & 1.22 & 1,19 & 1,20 \\
\hline Німеччина & 13,7 & - & 14,2 & - & 15,0 & - & 2,80 & 2,87 & 2,82 & 2,87 & 2,91 & 2,92 & 3,02 \\
\hline Польща & 6,6 & 6,8 & 7,2 & 7,4 & 7,5 & 8,3 & 0,75 & 0,88 & 0,87 & 0,94 & 1,00 & 0,96 & 1,03 \\
\hline Румунія & 3,1 & 3,4 & 3,4 & 3,3 & 3,3 & 3,4 & 0,50 & 0,48 & 0,39 & 0,38 & 0,49 & 0,48 & 0,50 \\
\hline Україна & 6,8 & 6,3 & 6,0 & 5,6 & 5,5 & 3,9 & 0,65 & 0,67 & 0,70 & $\mathbf{0 , 6 0}$ & 0,55 & 0,48 & 0,45 \\
\hline
\end{tabular}

Джерело: [15, с. 62] 
2019 р. понизилася з 61 місця до 63. Усього досліджувалося 125 країн (табл. 3).

Отже, домінування того чи іншого укладу в економіці конкретної країни безпосередньо відображається на структурі національної економіки та характеризує їі прогресивність [12, с. 105-106]. Щоб Україна не відставала від передових країн світу й вийшла на орбіту VI технологічного укладу, вона має робити ставку на розвиток високотехнологічних галузей.

Організація економічного співробітництва та розвитку (англ. OECD), визначаючи такі галузі (види діяльності), враховує три складові частини, а саме частку витрат на НДДКР у витратах підприємств галузі; частку високотехнологічної комплектації у складі виробів; частку персоналу НДДКР у складі підприємств [17]. Серед таких галузей слід назвати мікроелектроніку; інформаційні технології; обчислювальну техніку; програмування; робототехніку; нанотехнології; атомну енергетику; аерокосмічну техніку; біотехнології; фармацевтику; генну інженерію; штучний інтелект.

В Україні пріоритетність високотехнологічного виробництва закріплена законодавчо. Зокрема, ст. 4 Закону України «Про пріоритетні напрями інноваційної діяльності в Україні» визначає такі стратегічні пріоритети на 2011-2021 рр., як освоєння нових технологій транспортування енергії, впровадження енергоефективних, ресурсозберігаючих технологій, освоєння альтернативних джерел енергії; освоєння нових технологій високотехнологічного розвитку транспортної системи, ракетно-космічної галузі, авіа- й суднобудування, озброєння та військової техніки; освоєння нових технологій виробництва матеріалів, їх оброблення та з'єднання, створення індустрії наноматеріалів та нанотехнологій; технологічне оновлення та розвиток агропромислового комплексу; впровадження нових технологій та обладнання для якісного медичного обслуговування, лікування, фармацевтики; широке застосування технологій більш чистого виробництва та охорони навколишнього природного середовища; розвиток сучасних інформаційних, комунікаційних технологій, робототехніки [18].

Як підтвердження необхідності розвитку високотехнологічного виробництва групою експертів у рамках проєкту 3 передбачення структури майбутньої економіки України у середньостроковому (до 2020 р.) і довгостроковому (до 2030 р.) часових горизонтах на основі методу Дельфі було визначено іiі 10 основних драйверів. Експерти дійшли висновку, що на зазначених часових горизонтах Україна може досягти успіху в міжнародному поділі праці з огляду на своє географічне розташування, наявний людський потенціал, природні ресурси, розвиваючи такі драйвери економіки (табл. 4).

Згідно з академіком Б. Данилишиним, драйвери економічного зростання - це сукупність механізмів, які вловлюють попит, каталізують імпульси, що йдуть від нього, включають на відповідному етапі різні активи (матеріальні, фінансові, інформаційні, трудові) в русло руху, змінюють економічну ситуацію в країні. Основною функцією драйвера $є$ формування системи вертикальних і горизонтальних зв'язків, що вловлюють та поширюють імпульси, що йдуть від точок зростання на окремих ринках. Економіка України зростає чотири роки поспіль (2016-2019 рр.), і всі ці роки основним драйвером економічного зростання, за словами академіка, $є$ внутрішнє споживання, яке позитивно відбилось на сільському господарстві, будівництві та торгівлі [19].

Щоби економічне зростання країни не припинялось, необхідно постійно аналізувати старі драйвери та шукати нові. У тактичному плані Б. Данилишин вважає, що драйверами зростання у середньостроковій перспективі можуть бути аграрний сектор і розвиток транспортно-логістичної інфраструктури.

Як бачимо, думка науковців, експертів є близькою й мало розходиться із законодавчими деклараціями. 3 одного боку, це добре, але є певні розбіжності вітчизняних і міжнародних економічних експертів, зокрема, щодо перспектив розвитку аграрного сектору. Як було зазначено вище, експерти ВЕФ вважають, що необхідно зменшувати частку сільськогосподарської продукції у структурі ВВП країн (до 3-4\%), бо це є невисокотехнологічною галуззю, продукція якої не може створювати високу додану вартість.

Зупинимось на цій проблемі детальніше, адже в Україні наявна дещо інша ситуація з аграрною сферою, ніж у розвинутих країнах світу.

За результатами 2018 p. зовнішньоторговельний обіг агропродукції склав 24,3 млрд. дол., 3 яких 18,8 млрд. дол. припали на агроекспорт, що склало $39,8 \%$ у загальному експорті України. Найбільші

Таблиця 3

Значення основних критеріїв Глобального індексу конкурентоспроможності талантів для України за 2016-2019 рр.

\begin{tabular}{|c|c|c|c|c|}
\hline Критерій & Рейтинг 2016 р. & Рейтинг 2017 р. & Рейтинг 2018 р. & Рейтинг 2019 р. \\
\hline Ринкові та нормативні можливості & 91 & 103 & 99 & 96 \\
\hline Індекс приваблювання талантів & 97 & 94 & 98 & 105 \\
\hline Шанси для кар’єрного зростання & 72 & 64 & 66 & 68 \\
\hline $\begin{array}{l}\text { Індекс утримання талантів або здатність утримувати } \\
\text { кваліфікований персонал }\end{array}$ & 56 & 54 & 58 & 66 \\
\hline Виробничі навички співробітників & 40 & 66 & 44 & 45 \\
\hline Глобальні знання & 61 & 53 & 42 & 37 \\
\hline Глобальний індекс конкурентоспроможності талантів & 66 & 69 & 61 & 63 \\
\hline
\end{tabular}
Джерело: [16] 
Таблиця 4

Головні драйвери майбутньої економіки України

та пріоритетність їх вкладу в загальне зростання [8, с. 46]

\begin{tabular}{|c|l|c|c|c|}
\hline № & \multicolumn{1}{|c|}{ Драйвер (кластер) економіки } & $\begin{array}{c}\text { Внесок у загальне } \\
\text { зростання економіки, } \\
\mathbf{( \% ) , ~ 2 0 2 0 ~ p . ~}\end{array}$ & $\begin{array}{c}\text { Внесоку загальне } \\
\text { зростання економіки, } \\
\mathbf{( \% ) , ~ 2 0 3 0 ~ p . ~}\end{array}$ & $\begin{array}{c}\text { Часовий інтервал } \\
\text { зростання кластеру } \\
\text { економіки (роки) }\end{array}$ \\
\hline D1 & Аграрний сектор & 19 & 24 & $2015-2020$ \\
\hline D2 & Військово-промисловий комплекс & 15 & 17 & $2015-2030$ \\
\hline D3 & $\begin{array}{l}\text { Інформаційно-комунікаційні } \\
\text { технології }\end{array}$ & 9 & 8 & $2015-2025$ \\
\hline D4 & $\begin{array}{l}\text { Створення нових речовин, } \\
\text { матеріалів, нанотехнологій }\end{array}$ & 5 & 8 & $2020-2025$ \\
\hline D5 & Нова енергетика & 5 & 7 & $2020-2030$ \\
\hline D6 & $\begin{array}{l}\text { Високотехнологічне машино-, } \\
\text { приладобудування }\end{array}$ & 5 & 7 & $2025-2030$ \\
\hline D7 & Розвиток транзитної інфраструктури & 5 & 7 & $2017-2030$ \\
\hline D8 & $\begin{array}{l}\text { Біомедична інженерія, клітинна } \\
\text { медицина, фармація }\end{array}$ & 2 & 5 & $2017-2025$ \\
\hline D9 & Туризм & 2 & 5 & $2015-2030$ \\
\hline D10 & $\begin{array}{l}\text { Інші кластери (переважно низько } \\
\text { технологічні та сировинні) }\end{array}$ & 35 & & 2020 \\
\hline
\end{tabular}

частки аграрного експорту сформували зернові культури $(38,4 \%)$, масла $(23,3 \%)$ й насіння олійних культур $(10,2 \%)$. Найбільшими імпортерами української сільгосппродукції у 2018 р. були Індія, куди було експортовано продукції АПК на суму понад 1,8 млрд. дол., Китай (1,2 млрд. дол.), Нідерланди (1,2 млрд. дол.) та Іспанія (1 млрд. дол.). 3 травня 2018 р. по квітень 2019 р. Україна увійшла в трійку найбільших експортерів сільськогосподарської продукції в СС, продавши йому аграрної продукції на 6,3 млрд. євро [20].

Якщо поглянути на структуру доданої вартості за видами економічної діяльності у 2018 р., то необхідно зазначити, що вона не відповідає вимогам VI і навіть $\mathrm{V}$ технологічного укладу, бо іiі частка за основними високотехнологічними видами діяльності $\epsilon$ малою (наприклад, виробництво комп'ютерів, електронної та оптичної продукції має $0,4 \%$, наукові дослідження та розробки - 0,5\%, комп'ютерне програмування, консультування $-2,1 \%$, освіта $-0,2 \%$ ). Найвищою вона була в оптовій торгівлі (15,4\%), сільському господарстві, мисливстві та пов'язаних з ними послугах (7,8\%), а також виробництві харчової продукції, напоїв і тютюнових виробів (4,9\%) (табл. 5). Це означає, що для нашого ВВП та експорту продукція АПК все ще має велике значення.

Вважаємо, що стосовно перспектив розвитку АПК в Україні необхідно сформувати особливий підхід 3 огляду на наявні світові тренди економічного розвитку, внутрішні умови господарювання та національні економічні інтереси й визначені пріоритети. Він може мати такі наслідки.

1) Продовження нарощування сільськогосподарського експорту, але з акцентом на продукцію з вищою доданою вартістю (насіннєвий матеріал, кінцева сільськогосподарська продукція (мука, олія, маргарин, тверді сири, молоко, вершки, ковбасні вироби) тощо). Слід зазначити, що додана вартість для різних видів агропродукції у сучасній постіндустріальній економіці формується залежно не лише від кількості технологічних процесів іiі переробки, але й від інших факторів. Зокрема, це якість аграрної продукції, іiї безпечність та органічність походження, місце виробництва, кінцеве призначення, бренд.

2) Скорочення витрат, підвищення обсягів виробництва, продуктивності праці та якості сільськогосподарської продукції шляхом стимулювання агрокомпаній, дрібних фермерських, сімейних господарств впроваджувати новітні технології організації та ведення бізнесу (сільськогосподарська електротехніка, роботизація окремих процесів, системи автопілоту та навігації, органічні технології тощо).

3) Стимулювання розвитку інноваційних форм ведення агробізнесу (інтегрованих утворень (кластерів, бізнес-інкубаторів, агротехнопарків), самостійних агроформувань (сімейних, зокрема міських, ферм, екопоселень, агропарків, садиб зеленого та сільського туризму)) шляхом запровадження податкових, амортизаційних, кредитних та інших пільг.

4) Інвестування в НДР у сільському господарстві, що допоможе швидшими темпами переходити до інноваційного шляху розвитку аграрної сфери на засадах V та VI технологічних укладів.

Річна внутрішня дохідність інвестицій у НДР в цій галузі становить у провідних агрокраїнах 20-35\%. Позитивний вплив таких інвестицій на вартість сільськогосподарської продукції, визначений за співвідношенням витрат і доходів, становить приблизно 6-12\% (залежно від країни) [20].

Висновки. Проведене дослідження та наведені й проаналізовані дані дають підставу зробити такі висновки:

- формуються нові тренди світового економічного розвитку, які пов'язані зі вступом розвинутих економік до VI технологічного укладу, і Україна не може залишатися осторонь цих процесів, а має активно включатися шляхом розвитку високотехнологічних виробництв; 
Таблиця 5

Додана вартість за витратами виробництва суб'єктів господарювання за окремими видами економічної діяльності у 2018 р.

\begin{tabular}{|c|c|c|c|}
\hline Вид економічної діяльності & $\begin{array}{c}\text { Код за КВЕД-2010 } \\
\text { (рівень розділу) }\end{array}$ & Сума, тис. грн. & Частка, \% \\
\hline Усього & & 2510656579,2 & 100 \\
\hline $\begin{array}{l}\text { Сільське господарство, мисливство та надання пов'язаних із } \\
\text { ними послуг }\end{array}$ & 01 & 195346477,3 & 7,8 \\
\hline Добування сирої нафти та природного газу & 06 & 111229083 & 4,4 \\
\hline Виробництво харчових продуктів, напоїв і тютюнових виробів & $10+11+12$ & 124275725,5 & 4,9 \\
\hline $\begin{array}{l}\text { Виробництво основних фармацевтичних продуктів і } \\
\text { фармацевтичних препаратів }\end{array}$ & 21 & 14530414,6 & 0,6 \\
\hline Металургійне виробництво & 24 & 85091003,3 & 3,4 \\
\hline Виробництво комп'ютерів, електронної та оптичної продукції & 26 & 9245266,3 & 0,4 \\
\hline Виробництво машин та устаткування & 28 & 29389602,2 & 1,2 \\
\hline Будівництво будівель & 41 & 43662602,1 & 1,7 \\
\hline $\begin{array}{l}\text { Оптова торгівля, крім торгівлі автотранспортними засобами та } \\
\text { мотоциклами }\end{array}$ & 46 & 387876108,7 & 15,4 \\
\hline Наземний і трубопровідний транспорт & 49 & 119403467,9 & 4,8 \\
\hline $\begin{array}{l}\text { Складське господарство та допоміжна діяльність у сфері } \\
\text { транспорту }\end{array}$ & 52 & 93223859,5 & 3,7 \\
\hline Телекомунікації (електрозв’язок) & 61 & 38037302,4 & 1,5 \\
\hline Комп’ютерне програмування, консультування & 62 & 51516656,3 & 2,1 \\
\hline $\begin{array}{l}\text { Надання фінансових послуг, крім страхування та пенсійного } \\
\text { забезпечення }\end{array}$ & 64 & 26876712,9 & 1,1 \\
\hline $\begin{array}{l}\text { Діяльність головних управлінь (хедофісів); консультування з } \\
\text { питань керування }\end{array}$ & 70 & 80180461,6 & 3,2 \\
\hline $\begin{array}{l}\text { Діяльність у сферах архітектури та інжинірингу; технічні } \\
\text { випробування та дослідження }\end{array}$ & 71 & 19357445,3 & 0,8 \\
\hline Наукові дослідження та розробки & 72 & 12391099,3 & 0,5 \\
\hline Освіта & 85 & 3835756,7 & 0,2 \\
\hline Охорона здоров'я & 86 & 21882565,5 & 0,9 \\
\hline
\end{tabular}

Джерело: розраховано автором за даними Держстату Украйни

- необхідно грунтовніше підходити до формування національних економічних пріоритетів 3 огляду не лише на внутрішні чинники, але й на зовнішні тенденціiі, щоб у майбутньому не наздоганяти «ціле життя» розвинуті країни;

- слід диверсифікувати діяльність шляхом стимулювання розвитку креативних, інноваційних видів підприємництва як основних драйверів економічного зростання в постіндустріальному суспільстві;

- робити високу ставку на розвиток аграрної сфери в Україні як однієї з драйверів іії економічного зростання в майбутньому, однак не забувати про баланс між валютними надходженнями до бюджету, продовольчою безпекою в державі, досить високою зайнятістю у цій галузі та ризиком щодо можливості закріплення за Україною на світовому ринку кліше сировинного придатку.

Отже, в розрізі подальших наукових досліджень більшу увагу необхідно приділяти новітнім розробкам, технологіям та джерелам їх фінансування у тих видах діяльності, які можуть уже у середньостроковій перспективі (до 2025 р.) вагомо вплинути на економічне зростання в країні.

\section{Список літератури:}

1. Roco M., Bainbridge W. (eds). Converging Technologies for Improving Human Performance: Nanotechnology, Biotechnology, Information Technology and Cognitive Science. Arlington, 2004.

2. Глазьев С. Открытие закономерности смены технологических укладов в ЦЭМИ АН СССР. Экономика и математические методыл. 2018. Т. 54. № 3. С. 17-30.

3. Кондратьев Н. Большие циклы конъюнктуры. Москва : РАНИОН, 1928.

4. Mensch G., Schnopp, R. Stalemate in Technology, 1925-1935: The Interplay of Stagnation and Innovation. Historische Konjunkturforschung / W.H. Schröder, R. Spree (eds.). Stuttgart : Klett-Cotta, 1980. P. 60-74. URL: https://nbnresolving.org/ urn:nbn:de:0168-ssoar-340157 (дата звернення 01.03.2020).

5. Freeman C. As Time goes by // From Industrial Revolutions to the Information Revolution. Oxford : Oxford University Press, 2001

6. Шумпетер Й.А. Теория экономического развития / пер. с англ. В. Автономова и др. Москва : Прогресс, 1982 ; Директмедиа Паблишинг, 2008. 355 с. 
7. Бажал Ю. Інформаційна економіка. Роль інформації у формуванні ринкової економіки : монографія / за заг. ред. I. Розпутенка. Київ : К.І.С., 2004. С. 33-57.

8. Форсайт економіки України: середньостроковий (2015-2020 роки) і довгостроковий (2020- 2030 роки) часові горизонти / наук. керівник проекту М. Згуровський. Київ : НТУУ «КПІ», 2015. 136 с.

9. Львов Д., Глазьев С. Теоретические и прикладные аспекты управления НТП. Экономика и математические методы. 1986. Т. 22. Вып. 5. С. 793-804.

10. Глазьев С. Нанотехнологии как ключевой фактор нового технологического уклада в экономике / под ред. В. Харитонова. Москва : Тровант, 2009. 304 с.

11. Чухно А., Юхименко П., Леоненко П. Інституціонально-інформаційна економіка : підручник. Київ, 2010.687 с.

12. Конкурентоспроможність національної економіки: тенденції, перспективи, соціальні орієнтири : монографія / А. Грищук, Н. Данилевич, О. Макара, С. Урба, 3. Юринець. Луцьк : Вежа - Друк, 2012. 292 с.

13. Жмеренеиький О. Глобальні економічні тренди та Україна без майбутнього. Економічна правда. 2017. URL: https://www.epravda. com.ua/publications/ 2017/07/17/627005 (дата звернення: 01.03.2020).

14. Писаренко Т., Кваша Т. Стан інноваційної діяльності та діяльності у сфері трансферу технологій в Україні у 2018 році : аналітична довідка. Київ : УкрIНTЕI, 2019. 80 с.

15. Наукова та інноваційна діяльність України : статистичний збірник. Київ : Держстат, 2019. 107 с. URL: http://www.ukrstat.gov.ua/druk/publicat/kat_u/2019/zb/09/zb nauka_2018.pdf (дата звернення: 02.03.2020).

16. The Global Talent Competitiveness Index 2019. URL: https://gtcistudy.com/wpcontent/uploads/2019/01/GTCI2019-Report.pdf (дата звернення: 02.03.2020).

17. Hatzichronoglou T. Revision of the High-Technology Sector and Product Classification: OECD library. OECD Science, Technology and Industry Working Papers. Paris : OECD Publishing, 1997. 1997/2. 26 p.

18. Про пріоритетні напрями інноваційної діяльності в Україні : Закон України від 8 вересня 2011 p. URL: https://zakon.rada.gov.ua/laws/card/3715-17 (дата звернення: 01.03.2020).

19. Данилишин Б. Про драйвери зростання економіки України. HB. 2019. URL: https://nv.ua/ukr/opinion/prodrayveri-zrostannya-ekonomiki-ukrajini -50010791.html (дата звернення: 03.03.2020).

20. Данилишин Б. Чи може Україна продовжувати нарощувати експорт сільгоспродукції? Укрінформ. 2019 URL: https://www.ukrinform.ua/rubric-economy/2785567-ci-moze-ukrainaprodovzuvati-narosuvati-eksport-silgospprodukcii. html (дата звернення: 03.03.2020).

\section{References:}

1. Roco M., Bainbridge W. (eds) (2004) Converging Technologies for Improving Human Performance: Nanotechnology, Biotechnology, Information Technology and Cognitive Science. Arlington.

2. Glazev S. (2018) Otkryitie zakonomernosti smenyi tehnologicheskih ukladov v TSEMI AN SSSR. [The discovery of the laws governing the change of technological modes at the CEII the USSR Academy of Sciences]. Economics and mathematical methods, vol. 3, pp. 17-30 (in Russian).

3. Kondratev N. (1928) Bolshie tsiklyi kon'yunkturyi. [Big business cycles]. Moscow : RANION (in Russian).

4. Mensch, G., \& Schnopp, R. (1980). Stalemate in Technology, 1925-1935: The Interplay of Stagnation and Innovation. In W. H. Schröder, \& R. Spree (Eds.), Historische Konjunkturforschung (pp. 60-74). Stuttgart: Klett-Cotta. Available at: https://nbnresolving.org/urn:nbn:de:0168-ssoar-340157 (accessed: 01.03.2020).

5. Freeman C. (2001) As Time goes by // From Industrial Revolutions to the Information Revolution. Oxford : Oxford University Press.

6. Shumpeter Y. (2008) Teoriya ekonomicheskogo razvitiya [Theory of Economic Development]. Moscow : Direktmedia Pablishing. 355 p. (in Russian).

7. Bazhal Yu. (2004) Informatsiyna ekonomika. [Information Economy]. Kyiv : K.I.S., pp. 33-57 (in Ukrainian).

8. Forsayt ekonomiki Ukrainy: serednostrokoviy (2015-2020 roki) I dovgostrokoviy (2020-2030 roki) chasovI gorizonti [Foresight of Ukraine's economy: medium-term (2015-2020) and long-term (2020-2030) time horizons]. Kyiv : NTUU "KPI”, 2015. 136 p. (in Ukrainian).

9. Lvov D., Glazev S. (1986) Teoreticheskie i prikladnyie aspektyi upravleniya NTP [Theoretical and applied aspects of NTP management]. Economics and mathematical methods, t. 22, vol. 5, pp. 793-804 (in Russian).

10. Glazev S. (2009) Nanotehnologii kak klyuchevoy faktor novogo tehnologicheskogo uklada v ekonomike [Nanotechnology as a key factor in the new technological structure in the economy]. Moscow : Trovant, 304 p. (in Russian).

11. Chuhno A [ta in.]. (2010) Institutsionalno-Informatsiyna ekonomika [Institutional Information Economics]. Kyiv. 687 p. (in Ukrainian).

12. Hryschuk A. [ta in.]. (2012) Konkurentospromozhnist natsionalnoyi ekonomiki: tendentsiy, perspektivi, sotsialni orientiri : monografiya [Competitiveness of the national economy: trends, prospects, social guidelines : monograph]. Lutsk : Vezha - Druk. 292 p. (in Ukrainian).

13. Zhmerenetskiy O. (2017) Globalni ekonomichni trendy ta Ukraina bez maybutnogo. Ekonomichna pravda [Global economic trends and Ukraine without a future]. Economic truth. 2017. Available at: https://www.epravda.com.ua/publications/ 2017/07/17/627005 (accessed: 01.03.2020) (in Ukrainian).

14. Pysarenko T., Kvasha T. [ta in.]. (2018) Stan innovatsiynoi diyalnosti ta diyalnosti u sferi transferu tehnologiy v Ukraini u 2018 rotsi: analitichna dovidka. [State of Innovation and Technology Transfer Activity in Ukraine in 2018: Analytical Reference]. Kyiv : UkrINTEI. 80 p. (in Ukrainian). 
15. Naukova ta InnovatsIyna dIyalnIst UkraYini: statistichniy zbIrnik (2019) [Scientific and Innovative Activity of Ukraine: Statistical Collection]. Kyiv : Derzhstat, 107 p. Available at: http://www.ukrstat.gov.ua/druk/publicat/kat_u/2019/ zb/09/zb_nauka_2018.pdf (accessed: 02.03.2020) (in Ukrainian).

16. The Global Talent Competitiveness Index 2019. Available at: https:/gtcistudy.com/wpcontent/uploads/2019/01/ GTCI-2019-Report.pdf (accessed: 02.03.2020).

17. Hatzichronoglou T. Revision of the High-Technology Sector and Product Classification: Сайт OECD library / T. Hatzichronoglou // OECD Science, Technology and Industry Working Papers. Paris: OECD Publishing, 1997. 1997/2. 26 p.

18. Pro priorytetni napriamy innovatsiinoi dialnosti v Ukraini : Zakon Ukrainy vid 8 veresnia $2011 \mathrm{r}$ [On Priority Areas of Innovation in Ukraine: Law of Ukraine of September 8, 2011]. Available at: https://zakon.rada.gov.ua/laws/card/3715-17 (accessed: 01.03.2020) (in Ukrainian).

19. Danylyshun B. (2019) Pro drayvery zrostannya ekonomiky Ukrainy [About drivers of growth of economy of Ukraine]. NV. Available at: https://nv.ua/ukr/opinion/pro-drayveri-zrostannya-ekonomiki-ukrajini-50010791.html (accessed: 03.03.2020) (in Ukrainian).

20. Danylyshun B. (2019) Chy mozhe Ukraina prodovzhuvaty naroschuvaty eksport silgosproduktsii? [Can Ukraine continue to increase exports of agricultural products?]. Ukrinform. Available at: https:/ /www.ukrinform.ua/rubriceconomy/2785567-ci-moze-ukrainaprodovzuvati-narosuvati-eksport-silgospprodukcii.html （accessed: 03.03.2020) (in Ukrainian).

\title{
НЕОБХОДИМОСТЬ СМЕНЫ ТЕХНОЛОГИЧЕСКОГО УКЛАДА НА ОСНОВЕ ДРАЙВЕРОВ ЭКОНОМИЧЕСКОГО РОСТА
}

\begin{abstract}
В статье исследовань сущность категории «технологический уклад», его технологическое ядро, изменение технологических укладов в ходе экономического развития. Осуществлен критический анализ состояния экономического развития Украины в соответствии с принщипами высиих технологических укладов. Проанализировань основные мировые тенденции экономического роста, отечественные законодательные инициативы касательно инновационных принцииов развития, на основе чего обоснована необходимость создания предпосылок для перестройки экономики Украины на принципах VI технологического уклада. Определена сущность понятия «драйверы экономического роста». Осуществлен анализ отдельных драйверов экономического роста в стране касательно создания добавленной стоимости по затратам производства субъектов хозяйствования по отдельным видам экономической деятельности. Предложень рекомендации касательно будущего развития аграрной сферь Украины как одного из драйверов экономического роста.
\end{abstract}

Ключевые слова: технологический уклад, инновачии, научные исследования и разработки (НИР), высокотехнологичные отрасли, NBIC-конвергенция, драйверы экономического роста, аграрная сфера.

\section{THE NECESSITY OF CHANGING TECHNOLOGICAL CONDITION ON THE BASIS OF ECONOMIC GROWTH DRIVERS}

The article states the dominance of a particular way in the economy of a particular country directly reflects on the structure of the national economy and characterizes its progressiveness. Therefore, a critical analysis of the state of economic development of Ukraine in accordance with the principles of higher technological structures. The study noted that due to the high dynamic market of new technologies in the world global and information field of business suppliers, new problems still remain, which are used with all the necessary active work boxes, using the necessary technologies and economic economy in Ukraine and moving to the highest economic level. In the modern period of technological time development, it is very important. Who pioneers the market for new modern technologies; he will win and succeed in the short and medium term. In the present study shows in order for Ukraine to keep up with the leading countries in the world and enter the orbit of the VI technological institution, it must focus on the development of high-tech industries and drivers of economic growth: information and communication technologies, high-tech machine and instrument making, creation of new substances and materials, nanotechnology, biomedical engineering, cellular medicine, pharmacy, tourism, agricultural sector etc. The research shows it is necessary to approach the formation of national economic priorities more thoroughly, taking into account not only internal factors but also external trends; diversify activities by stimulating the development of creative, innovative types of entrepreneurship as the main drivers of economic growth. The essence of the concept of "drivers of economic growth" is defined. The analysis of individual drivers of economic growth in the country in terms of value added at the cost of production of economic entities by specific types of economic activity. Placing a high emphasis on the development of the agricultural sector in Ukraine as one of the drivers of its economic growth in the future, do not forget about the balance between foreign exchange budgetary payments, food security in the country, sufficiently high employment in this sector and the risk of anchoring Ukraine in the world the market cliché of raw material appendage.

Key words: technological structure, innovation, research and development $(R \& D)$, high-tech industries, NBIC convergence, drivers of economic growth, agricultural sector. 